\title{
ENYEDI, A REGIONÁLIS TUDOMÁNY ALAPÍTÓJA
}

Enyedi György professzor úr köszöntésénél elsőként személyes élményeimet kell megosztani, hiszen ezek jellemzik azt a személetmódot és emberi, kollegiális mentalitást, amely jellemezte és jellemzi öt. A nyolcvanas évek közepén súlyos emberi és szakmai válságban voltam, amiből nem tudtam elmozdulni. Akkor Gyurka felkért, hogy dolgozzam fel az iparszerü mezőgazdasági rendszerek területi terjedését, azok térbeli hálózatának rendszerét. Ez a felkérés és az erre épülő kutatás vezetett el az innovációk térbeli terjedésének kutatásához, ami kimozdított a passzív állapotomból és majd az egész életpályámat meghatározta. Ezzel a kutatási programmal indult el a közel három évtizedes szakmai és emberi kapcsolatunk, ami - bízom benne -, hogy még sokáig tart.

Az MTA Regionális Kutatások Központja megalakítása és szervezeti kiépítése azon a gondolaton alapult, hogy a térrel foglalkozó új tudománynak egy országos hálózatot kell létrehozni és müködtetni. A nyolcvanas években ez izgalmas újdonságnak számított. Ezt a friss gondolatot sikerült egy fiatal csapattal megvalósítani, közgazdászokkal, jogászokkal, földrajzosokkal, szociológusokkal, akik megérezték a térbeliség adta nyitottság - pontosabban szakmai együttgondolkodás - esélyét, egy szabadabb, adott diszciplínától nem meghatározott gondolkodás és kutatás lehetőségét. Az időszak is szerencsés volt, mert a rendszerváltozás éveiben nőtt fel és erösödött meg az RKK és körének kutatói potenciálja, és ebben a szárnyaló, közel tíz esztendőben lehetett és kellett új megoldásokról, intézményekről álmodozni.

A regionális tudomány folyamatosan fejlődött, megindult a képzés a szakterületen, a kilencvenes évek közepétől a MTA doktora címre érett kutatók jelentkeztek, a doktori képzés elkezdődött, a szakterület oktatása terjedt az intézményekben, kiépült a tudományos infrastruktúra (MTA bizottság, folyóirat, akadémiai intézet, elméleti szakkönyvek, nemzetközi kapcsolatok, folyamatosan jelentkező hazai konferenciák). Mindezekben ott volt Gyurka figyelme, alakító észrevétele, segítsége, s tényleges bátorítása, ösztönzése. Alapvető, meghatározó reflexiókat adott az egyes kezdeményezésekhez, egy-egy alakító észrevétele ösztönözte a bizottság munkáját, doktori pályázatokhoz bíztató támogatást nyújtott, az intézet munkáját folyamatosan értékelte, irányadó konferenciákon újszerủ és izgalmas előadásokat tartott, elismerő recenziókat adott közre a nagyobb jelentőségü munkákról, s a jelenléte és szellemi sziporkákat megvillantó elnökségei számos eseményt meghatároztak. 
Ott van Enyedi György szellemi, tudományos hatása a hazai regionális tudományban, annak szervezeteiben, meghatározó szereplőinek, kutatóinak, professzorainak munkásságában. S az a csodálatos és egyben nagyszerü, hogy ezt a jelenlétet nem teherként éljük meg, hanem éppen ellenkezőleg: baráti, emberi, szakmai $\mathrm{s}$ mindenek fölött egyenrangú alkotó kapcsolatként.

Kedves Gyurka! Tudsz valami titkot, ami nélkül ma nem lenne regionális tudomány, s mi, a tanítványaid holnap nem lehetnénk a nagy műved folytatói!

Rechnitzer János

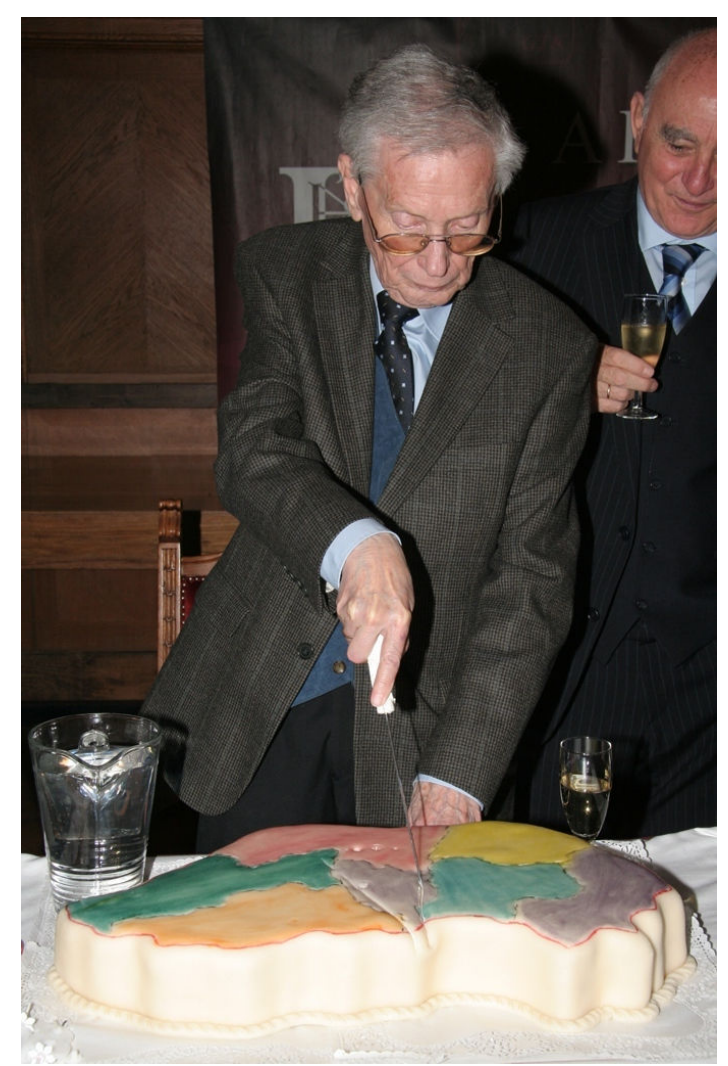

Fotó: Balázs Gusztáv. 